\title{
CORRESPONDENCE
}

\section{Science in Spain}

SIR - The present status of science in Spain is unworthy of an advanced society that values its standing in the community of nations. It is incumbent upon a modern state to develop a balanced policy of support for basic and applied science; a policy for the advancement of science must be the concern of government as much as economic, educational, foreign and military policy. Unfortunately our administration is derelict of this obligation; it is disregarding the creative aspects of science in favour of short-term pragmatism, typical of a colonial society.

As a matter of intellectual dignity, of national prestige and of responsibility to future generations, this situation must not persist. As Spanish scientists we demand that the administration respect our right to pursue our scientific interests, and we assume the responsibility for generating a scientific establishment that is both of value to our society and a credit to our country.

The efforts committed to this endeavour will be justifiable only if the resulting science and technology are competitive at the international level. In order to be competitive, technology must be original, and because of its modern complexity it depends on complete and continuous access to basic research. It is impossible to generate a competitive technology without a parallel reinforcement of research in basic science.

The extent of the task that confronts us can be evaluated by examination of the commitment to science in other countries in the European Community. The initial investment required to approach their levels is modest, both in absolute terms and in comparison with the cost of other national programmes. However, this effort must begin immediately, because the deterioration of our scientific institutions, the demoralization of our scientists and the loss to other countries of the most able, especially among the young, increases daily.

In order to invigorate our science, the university departments must become centres of scientific excellence, with a balanced dedication to preparing new professionals and to research. Moreover, because of the complexity of modern scientific investigation it is necessary not only to reorganize and strengthen existing research centres, such as the Research Council, the Nuclear Energy Commission and the Agricultureal Research Institute, but even to create new ones.

Our country cannot be expected to reach a satisfactory level of cultural and economic development or a minimum of political independence, if we do not soon recognize that progress depends on knowledge. State administrators must become aware of the necessity of stimulating sound scientific research and of the historical responsibility they have in this endeavour.

The above Manifesto has been signed by, among others, 134 professors, 25 associate professors of the University of Madrid, 23 research professors and 14 investigators of the Spanish Research Council, heads of departments or institutes in the areas of humanities, natural sciences, medicine and technology in nineteen major cities of the country (Barcelona, Bilbao, Córdoba, Granada, La Laguna, León, Lérida, Madrid, Málaga, Murcia, Oviedo, Pamplona, Salamanca, Santander, Santiago, Sevilla, Valencia, Valladolid and Zaragoza) besides 21 investigators, heads of research groups in the Spanish Atomic Energy Commission and several medical institutions.

A. Garcia.Beli.ido

Centro de Biologia Molecular,

Universidad Autónoma de Madrid, Madrid-34, Spain

\section{Nuclear electricity}

SIR - The article 'Nuclear generating costs compared' (Nature 21 August, p.753) states that the analysis of relative costs given in the 1979/80 Report of the Central Electricity Generating Board (CEGB) "is likely to be much quoted in the months ahead, when plans are being laid for the further development of . the British nuclear power programme". This is certainly true and it is therefore a pity that the report's figures were reproduced without question. In fact, for the purposes of comparison, the figures are almost totally misleading.

The apparent lower cost of nuclear (Magnox) electricity (1.30 pence per $\mathrm{kWh}$ against 1.56 pence per $\mathrm{kWh}$ for coal) is entirely an artefact of inflation. If currency had been stable over the lifetime of the Magnox stations (or if inflation had been corrected for in the accounts) the order would have been reversed. In 1980 prices the approximate corrected costs are 2.5 pence per $\mathrm{kWh}$ for electricity from nuclear stations and 1.9 pence per $\mathrm{kWh}$ from coal-fired stations ${ }^{1}$.

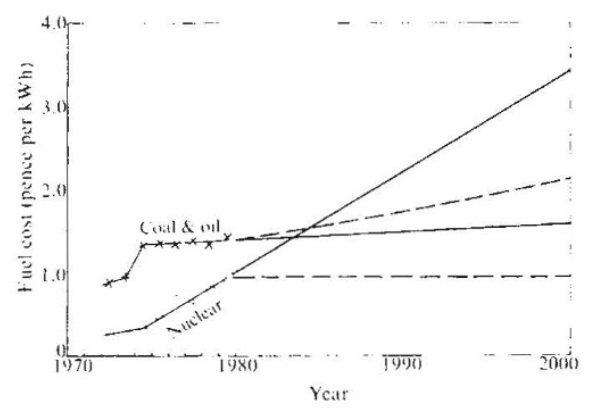

Fig. 1 Fuel costs from the 1979/80 CEGB Statistical Yearbook, Tables 9 and 10, from $1972 / 3$ to $1979 / 80$ in pence per $\mathrm{kWh}$ corrected to 1979/80 prices using the Retail Prices Index. Crosses, coal and oil combined; circles, nuclear. 1980-2000 extrapolations: solid line, linear: dashed line, CEGB extrapolation for net effective cost calculations.

The full calculation can only be undertaken when the CEGB decides that its present policy of withholding the data from which Table 1 in the Nature article was calculated is counterproductive, but all the indications are that the real cost of nuclear electricity in $1979 / 80$ was well over 50 per cent greater than that from coal-fired stations.

When we come to future costs (Table 3 in the Nature article) the figures are calculated in $1980 £$ 's. But here the figures are equally misleading for different reasons. Richard Marshall (Nature 18 September, p.184) has dealt with the CEGB's optimistic figures in the light of actual operating experience with regard to load factors. An equally optimistic view is taken of nuclear fuel costs relative to those of coal. Figure 1 shows the real costs of nuclear fuel for the last eight years. This rose quite rapidly for the first three years but then shot up at a rate of 0.12 pence per $\mathrm{kWh}$ per year to 0.94 pence per $\mathrm{kWh}$ in $1979 / 80$. The increase shows no sign of slowing down and if it continues nuclear fuel costs will overtake those of coal in the mid 1980s.

It is significant in respect of future fuel costs that the 1979/80 CEGB Report records with satisfaction that an understanding has been reached with the National Coal Board to take 75 million tons of coal a year provided that the real price of coal does not increase for five years, but "the terms of a contract with British Nuclear Fuels Ltd for reprocessing oxide fuel from the advanced gas-cooled reactor (AGR) stations have yet to be negotiated".

It is extraordinary that the CEGB has nevertheless nowhere, either in its reports or in the evidence to the Select Committee, discussed the alarming increase in real nuclear fuel costs (over 10 per cent per year for the last five years) but has concentrated on postulated increases in the real price of coal up to the end of the century. This hypothetical increase is actually incorporated into Table 3 . The figure of 2.38 pence per $\mathrm{kWh}$ for 'inclusive fuel costs' of a coal-fired station is composed of two parts. 1.36 pence per $\mathrm{kWh}$ is the approximate current fuel cost in March 1980 prices and the remainder, 1.02 pence per $\mathrm{kWh}$, is entirely dependent on the assumption about increases in coal costs up to the year 2000. If real future costs for coal are assumed to remain stable this part would be zero.

No such addition to current costs occurs with nuclear fuel. The figure of 0.61 pence per $\mathrm{kWh}$ in March 1980 prices hardly covers the increase due to inflation from the 0.55 pence per kWh given for Hinkley Point B in 1979/80 average prices, let alone any allowance for the rapid rise in real costs. There is no provision for "present value of future real increases in the price of fuel" in the nuclear case and this means that it is assumed there will be no real increases in the price of nuclear fuel over the 25 year lifetime of the station.

It is on the basis of such wild assumptions that the net effectiveness cost calculations over the whole lifetimes of the stations have produced the apparently favourable results for nuclear power.

It is difficult to see why the CEGB did not present the obvious calculation - the estimated cost in pence per $\mathrm{kWh}$ for each station in its year of commissioning in 1980 costs and prices - and then make the various points relevant to possible alterations in these costs in the future. But then these considerations would have been explicit and generally understandable, whereas wrapped in the computer program for finding net effective cost they are almost immune from criticism.

\section{J. W. JEFFERY}

Birkbeck College,

Malet Street, London WCI, UK

1. Jeffery, J.W. Energy Policy (in the press). 